\title{
ВПЛИВ ВЖИВАННЯ ХАРЧОВОЇ КЛІТКОВИНИ НА ХАРЧОВУ ПОВЕДІНКУ У ПАЦІЕНТІВ 3 НАДМІРНОЮ ВАГОЮ ТА ОЖИРІННЯМ
}

\author{
Жердьова Н. М. ${ }^{1,2}$, Степура О. А. ${ }^{1}$, Костіцька I. O. ${ }^{3}$, Мазій C. I. ${ }^{1}$ \\ ${ }^{1}$ ДНУ "Центр інноваційних медичних технологій НАН України», \\ м. Київ, Украӥна \\ ${ }^{2}$ Національний університет охорони здоров’я імені П.Л. Шупика МОЗ Украӥни, \\ м. Київ, Україна \\ ${ }^{3}$ Івано-Франківський національний медичний університет, \\ м. Івано-Франківськ, Украӥна \\ nadejda05.1977@gmail.com
}

Ожиріння - це глобальне та мультифакторне захворювання, яке асоціюеться з багатьма коморбідними станами [1], такими як кардіоваскулярні захворювання (КВЗ), метаболічний синдром, цукровий діабет, онкологічні захворювання та, за останніми даними, із COVID-19 [2]. За останні роки принципи клінічної практики щодо управління стилем життя та харчуванням у людей з ожирінням і цукровим діабетом 2 типу (ЦД2) стали рухатись до більш широкого та гнучкого розподілу нутрієнтів, який наголошуе на перевазі якості їжі над кількістю. Але для багатьох людей найскладнішою частиною будь-якої дієти залишаеться питання «що можна, а що не можна їсти» і як дотримуватись планів харчування. Американська діабетична асоціація зазначае, що планування прийому їжі мае бути індивідуалізованим, і "різноманітні режими харчування е прийнят- ними для лікування діабету 2 типу» [3]. Але навчання окремих паціентів щодо принципів харчування та зміни способу життя займають багато часу навіть за умов доступності кваліфікованих спеціалістів дієтологів, ендокринологів, психологів. Так, у дослідженні з вивчення поняття «зміна способу життя», а саме, здорове харчування та фізичне навантаження, не розуміли значення 77,33\% опитуваних [4]. Безумовно, на схеми харчування впливае доступність їжі, відчуття голоду чи ситості, соціальні звички, психологічні порушення, зручність. Порушення циркадних ритмів харчування, наприклад вночі, призводять до зниження рівня мелатоніну, і як наслідок, до інсулінорезистентності, ожиріння та ЦД2. В умовах порушення харчової поведінки відбуваеться порушення складу кишкової мікробіоти та зниження секреції L-клітинами кішківника глюкагоно-подіб-

\footnotetext{
* Автори гарантують колективну відповідальність за все, що опубліковано в статті.

Автори гарантують відсутність конфлікту інтересів та власної фінансової зацікавленості при виконанні роботи та написанні статті.

Рукопис надійшов до редакції 17.08.2021.
} 
ного пептиду-1 (ГПП1). Рецептори до ГПП1 виявлені в гіпоталамусі, де відбуваеться обробка інформації щодо апетиту та сприйняття їжі $[5,6]$. Саме тут ГПП1 стимулюе секрецію меланокортинів, які діють на рецептори в різних областях мозку, регулюючи відчуття голоду $[7,8]$. Однак, порушення вироблення меланокортину та ГПП1 є не единим аспектом регулювання ваги. Вважається, що смак їжі, включаючи їі запах, також відіграе важливу роль у регулюванні апетиту та розвитку ожиріння [9]. Дієта, багата на вуглеводи і насичені жири, може впливати на регуляцію апетиту через їх прозапальну дію на мікроглію в гіпоталамічних регіонах [10]. Дофамін є вирішальним фактором передачі винагороди системам мозку, хоча стимулювання апетиту залежить і від інших речовин, що сигналізують [11]. За результатами багатьох досліджень встановлено взаємний зв'язок між ожирінням, цукровим діабетом та порушенням когнітивних функцій, пов'язаними 3 навчанням та пам'яттю, що може бути пусковим механізмом надмірного споживання їжі та розвитку ожиріння [12]. Так, було показано, що одніею з причин набору ваги є інсулінорезистентність головного мозку [13]. Згідно багатьох проведених досліджень, актуальним є те, що для помітного зниження розвитку кардіо-васкулярного ризику у пацієнтів з надмірною вагою та ожирінням достатньо від 5\% до $10 \%$ втрати ваги $[14,15]$. Для досягнення успішного збереження втрати ваги з часом ВОО3 та ЄC [16], а також Академія харчування та дієтології США [17] рекомендують змінити спосіб життя, включаючи діету. Існуе декілька основних видів дієтотерапії: з низьким вмістом жирів; з низьким вмістом вуглеводів та високим - жирів; низьким вмістом вуглеводів та високим - білків; палеодіета (з високим вмістом білків); західна дієта; середземноморська дієта та їх різно- види [18]. Обов’язковим у всіх видах дієти є включення клітковини. Американська асоціація діетологів рекомендуе для чоловіків 34 г клітковини на добу, для жінок -28 г на добу. Позитивний вплив клітковини вивчений у багатьох дослідженнях. З'ясовано, що дієта з високим вмістом клітковини знижуе загальну смертність від КВЗ, інфекційних та респіраторних захворювань до $56 \%$ у чоловіків та $59 \%$ у жінок [19]. У аналізі 10 проспективних досліджень показано, що за умови вмісту клітковини більше 10 г/день ризик КВЗ знижуеться на 19\% [20]. Цікавою є знахідка щодо асоціації між кількістю вмісту клітковини у раціоні та зменшенням смертності від інфекції та респіраторних захворювань. Дослідження також показали, що клітковина мае протизапальні властивості, а саме, призводить до зниження рівня таких запальних маркерів, як С-реактивний білок, інтерлейкін-6, фактор некрозу пухлин, які відіграють роль у розвитку хронічних запальних станів [21-24]. Отже, дієтотерапія, збагачена клітковиною, повинна мати переваги щодо покращення метаболічних порушень, зниження ризику КВ3, загальної смертності, інфекційних захворювань. Але виникае питання щодо рутинної клінічної практики, де пацієнти іноді не можуть 3 якихось причин отримувати необхідну кількість клітковини із звичайних харчових продуктів. Українськими науковцями був розроблений препарат Інгуар ${ }^{\mathrm{TM}}$, який містить очищену та мікрогранульовану за спеціальною технологією гуарову камедь (харчова клітковина), що була отримана з ендосперму насіння Cyamopsis tetragonoloba. Тому метою нашого дослідження було вивчити вплив прийому очищеної та мікрогранульованої гуарової камеді у формі препарату Інгуар ${ }^{\text {TM }}$ на метаболічні показники та зміну харчової поведінки у паціентів з надмірною вагою та ожирінням.

\section{МАТЕРІАЛИ ТА МЕТОДИ}

У дослідження тривалістю 21 день були включені пацієнти з індексом маси тіла (IMT) більше 25 кг/м², старше 18 років. Пацієнти були розподілені на 2 групи по 30 осіб. До першої групи відносились пацієнти, які отримували препарат по 1 пак. (5 г) на вечір, до другої - які приймали препарат по 1 пак. 3 рази на день (15 г). Всім паціентам до та після лікування вимірювали антропометричні дані (IMT, вага, обсяг та- 
лії (ОT), обсяг стегон (ОС), обсяг передпліччя (ОП)), лабораторні показники (індекс HOMA-IR, глікемія плазми натще (ГПН), інсулін, тригліцериди (ТГ)). За допомогою опитувальника Eating Attitudes Test (EAT26) визначено наявність порушень харчової поведінки [25]. Голанський опитувальник харчової поведінки використовували для визначення типу харчової поведінки, а саме, екстернального, емоційного та обмежувального, з середніми значеннями 2,$7 ; 1,8$ та 2,4 бала відповідно [26].

\section{РЕЗУЛЬТАТИ ТА ЇХ ОБГОВОРЕННЯ}

Середній вік хворих в групі 1 становив $53,95 \pm 2,43$ роки, у другій $-58,28 \pm 2,07$ роки. Частка паціентів, хворих на ЦД2, становила $36,4 \%$ в першій групі, та $38,1 \%-$ в другій. В групі 1 середній показник IMT становив $33,35 \kappa 5 / \mathrm{M}^{2}$, хоча надмірна вага спостерігалась у 19,2\% пацієнтів, ожиріння 1 ступеня $-56,8 \%, 2$ ступеня $-19,2 \%$, 3 ступеня $-4,8 \%$. В групі 2 середній показник IMT становив $36,14 \mathrm{\kappa} / \mathrm{M}^{2}$, надмірна вага спостерігалась у $4,8 \%$ осіб, ожиріння 1 ступеня $-47,3 \%, 2$ ступеня $-28,7 \%$, 3 ступеня - 19,2\%. До того ж в обох групах спостерігався метаболічно нездоровий феIR вірогідно знизився.
Дані були аналізовані за допомогою програми SPSS версія 25. Описова статистика була проведена для отримання демографічних даних. Демографічні дані представлені як середне значення \pm стандартна похибка чи відсотки. Загальну лінійну модель (UNIANOVA) використовували для порівняння показників груп. Також для порівняння даних між групами використовували T-test. Різницю вважали вірогідною за рівня значущості $\mathrm{p}<0,05$.

нотип ожиріння за показником співвідношення OT/OC, який був більше 0,9. Також в обох групах відмічалось підвищення рівня глікемії натще, індексу НОМА та ТГ вище нормальних значень (див. табл. 1). Після лікування протягом 21 дня зниження показників IMT, рівня глікемії, індексу HOMA та ТГ в обох групах не були вірогідними. Тільки в групі, яка отримувала клітковину в кількості 15 г/добу, індекс НОМА-

Вивчаючи наявність порушення харчової поведінки за опитувальником ЕАТ-26 в групі 1 , тільки у $4,5 \%$ була спостереже-

Таблиця 1

Характеристика паціентів до та після лікування в групі, що приймала клітковину 5 г на добу (група 1) та 15 г на добу (група 2)

\begin{tabular}{|c|c|c|c|c|}
\hline \multirow[b]{2}{*}{ Показники } & \multicolumn{2}{|c|}{ Група $1(\mathrm{n}=30)$} & \multicolumn{2}{|c|}{ Група $2(n=30)$} \\
\hline & До лікування & $\begin{array}{c}\text { Після } \\
\text { лікування } \\
\end{array}$ & До лікування & $\begin{array}{c}\text { Після } \\
\text { лікування } \\
\end{array}$ \\
\hline Вік, роки & \multicolumn{2}{|c|}{$53,95 \pm 2,43$} & \multicolumn{2}{|c|}{$58,28 \pm 2,07$} \\
\hline Стать, \% (ж/ч) & \multicolumn{2}{|c|}{$77,3 / 22,7$} & \multicolumn{2}{|c|}{$47,6 / 52,4$} \\
\hline 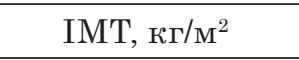 & $33,35 \pm 1,02$ & $32,85 \pm 1,04$ & $36,14 \pm 1,13$ & $35,82 \pm 1,16$ \\
\hline $\mathrm{OT}, \mathrm{cm}$ & $108,59 \pm 2,42$ & $105,00 \pm 2,33$ & $119,0 \pm 2,68$ & $116,5 \pm 2,34$ \\
\hline $\mathrm{OC}, \mathrm{cm}$ & $116,56 \pm 1,85$ & $113,00 \pm 2,16$ & $117,77 \pm 2,28$ & $115,02 \pm 1,58$ \\
\hline $\mathrm{OT} / \mathrm{OC}$ & $1,88 \pm 0,58$ & $1,90 \pm 0,06$ & $2,11 \pm 0,04$ & $2,11 \pm 0,04$ \\
\hline $\begin{array}{c}\text { Глікемія плазми } \\
\text { натще, ммоль/л }\end{array}$ & $7,47 \pm 0,62$ & $6,50 \pm 0,39$ & $7,88 \pm 0,65$ & $6,98 \pm 0,03$ \\
\hline HOMA-IR, ум. од. & $5,26 \pm 0,66$ & $4,11 \pm 0,56$ & $6,07 \pm 0,44$ & $4,26 \pm 0,41^{*}$ \\
\hline $\begin{array}{c}\text { Тригліцериди, } \\
\text { ммоль/л }\end{array}$ & $1,78 \pm 0,23$ & $1,38 \pm 0,15$ & $2,11 \pm 0,21$ & $1,71 \pm 0,16$ \\
\hline
\end{tabular}

Примітка:

* $\mathrm{p} \leq$ 0,05 - порівняно з особами до лікування. 


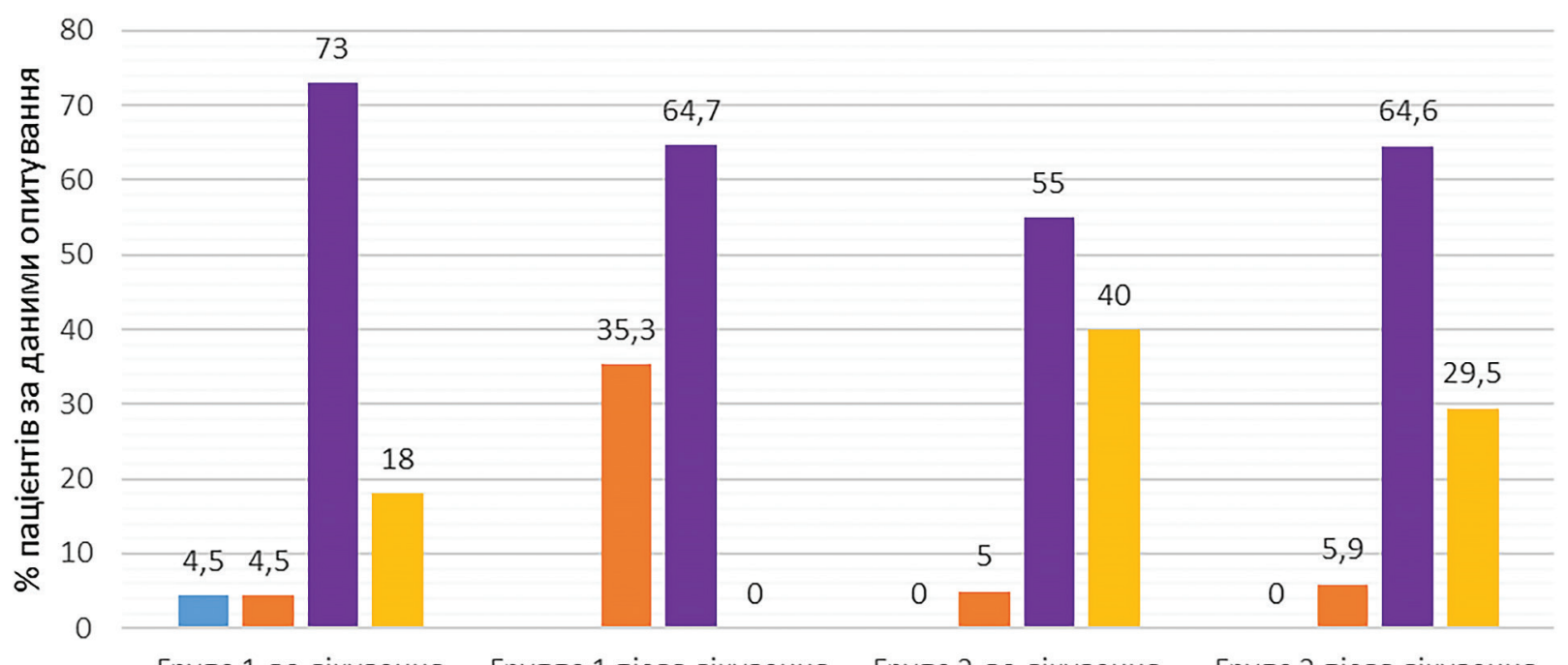

Група 1 до лікування Группа 1 після лікування Група 2 до лікування $\quad$ Група 2 після лікування

Групи по показниках хачової поведінки (в балах за опитувальником ЕАT-26)

$$
\square \text { 0-15 } \square \text { 16-30 } \square 31-45 \square 46-60
$$

Рисунок 1. Стан харчової поведінки за опитувальником ЕАТ-26 до та після лікування харчовою клітковиною.

на низька вірогідність порушення харчової поведінки, у 4,5\% - знижена вірогідність, 73,0\% мали середню вірогідність і 18,0\% підвищену вірогідність порушення харчової поведінки. В групі 2 у $40 \%$ опитуваних було виявлено підвищену вірогідність, у 55,0 \% середню і тільки у 5,0 \% - знижену (рис. 1).

Після проведеного курсу лікування в групі, яка отримувала 5 г харчової клітковини на вечір до основного харчування були відсутні особи з підвищеною вірогідністю розладів харчової поведінки, також зменшилась кількість осіб з середньою вірогідністю, та підвищилась до $35,3 \%$ кіль- кість осіб зі зниженою вірогідністю харчового розладу. В групі, яка отримувала 15 г харчової клітковини на добу, також зменшилась частка людей 3 підвищеною вірогідністю порушень харчової поведінки (з $40 \%$ до 29,5\%).

При вивчені типу харчового розладу за Голанським опитувальником харчової поведінки виявлено, що порушення обмежувальної харчової поведінки, тобто прагнення у жорстокому обмеженні їжі, виявлено у 81,9\% осіб в першій групі, та 78,9\% у другій. Емоціогенну харчову поведінку, а саме звичку заїдати емоції, виявлено у $59,4 \%$ осіб в першій групі та в $47,2 \%$

Таблиця 2.

\section{Зміна стану харчової поведінки (в балах) \\ за Голанським опитувальником харчової поведінки до та після лікування в групі, що приймала клітковину 5 г на добу} (група 1) та 15 г на добу (група 2)

\begin{tabular}{c|c|c|c|c|c|c}
\hline \multirow{2}{*}{$\begin{array}{c}\text { Тип харчової } \\
\text { поведінки }\end{array}$} & \multicolumn{3}{|c|}{ Група 1 } & \multicolumn{3}{c}{ Го } \\
\cline { 2 - 7 } & $\begin{array}{c}\text { Після } \\
\text { лікуванання } 2\end{array}$ & $\mathbf{P}$ & $\begin{array}{c}\text { До } \\
\text { лікування }\end{array}$ & $\begin{array}{c}\text { Після } \\
\text { лікування }\end{array}$ & P \\
\hline $\begin{array}{c}\text { Обмежувальна } \\
\text { харчова поведінка }\end{array}$ & $3,06 \pm 0,14$ & $3,49 \pm 0,12$ & 0,000 & $2,92 \pm 0,13$ & $3,21 \pm 0,14$ & 0,010 \\
\hline $\begin{array}{c}\text { Емоціогенна } \\
\text { харчова поведінка }\end{array}$ & $2,18 \pm 0,16$ & $2,03 \pm 0,24$ & 0,650 & $2,06 \pm 0,18$ & $1,96 \pm 0,17$ & 0,009 \\
\hline $\begin{array}{c}\text { Екстернальна } \\
\text { харчова поведінка }\end{array}$ & $3,23 \pm 0,11$ & $3,03 \pm 0,15$ & 0,001 & $3,11 \pm 0,11$ & $3,04 \pm 0,12$ & 0,001 \\
\hline
\end{tabular}


у другій. Екстернальна харчова поведінка відзначена у $85,7 \%$ та $73,6 \%$ опитуваних відповідно. Після лікування в групі, яка отримувала 5 г гуарової камеді в якості харчових волокон, збільшився відсоток пацієнтів з обмежувальною харчовою поведінкою до $94,1 \%$, як і в другій групі, де пацієнти отримували 15 г харчової клітковини на добу, і становив 83,3\%. В той же час відсоток з емоційною харчовою поведінкою зменшився до $35,2 \%$ та 44,2\% відповідно, а з екстернальною харчовою поведінкою до $70,6 \%$ та $66,5 \%$ відповідно.

Як видно, з таблиці 2 , в групі 2 вірогідно підвищилась саме обмежувальна харчова поведінка та знизилась емоціогенна й екстернальна. В той же час в групі 1 вірогідного впливу на емоціогенну харчову поведінку після лікування відзначено не було, хоча вірогідно знизилась екстернальна та підвищилась обмежувальна харчова поведінка.

Слід зазначити, що за результатами інших досліджень вживання харчової клітковини покращувало ліпідний профіль [27], знижувало рівень глікемії та інсулінорезистентності [28]. У нашому дослідженні ми спостерігали тенденцію до зниження IMT, ГПН, рівня ТГ в обох групах, яке не досягло статистичної значущості. Вірогідне зниження інсулінорезистентності спостерігали в групі, яка отримувала гуарову камедь у дозі 15 г на добу. За даними опитувальників у більшості випадків було отримано три типи порушення харчової поведінки, а саме обмежувальну, емоційну та екстернальну. До того ж в обох групах переважали саме обмежувальний та екстернальний типи порушень. Це $е$ цікавою комбінацією, тому що нездатність встояти перед смачною їжею, їі апетитним ароматом і виглядом (екстернальна харчова поведінка) та спробою обмежити вживання їжі, в результаті чого людина то сідае на жорстку дієту, то зривається з неї, з надлишком винагороджуючи себе за попередні обмеження і заборони (обмежувальна хар- чова поведінка), призводить до ще більшого набору ваги. Однією з причин порушення харчової поведінки є інсулінорезистентність, яка була підтверджена лабораторно у наших пацієнтів за показником НОМАIR, в тому числі головного мозку, наявність якої впливає на зниження когнітивних функцій, а саме, зниження контролю $[29,30]$. Відомим фактом є те, що інсулін при з'єднанні з рецепторами в гіпоталамусі знижуе потребу у їжі та вагу тіла, а також відчуття смакових якостей деяких продуктів, наприклад шоколаду, знижуючи до них потяг. Після проведеного лікування ми виявили вірогідне зниження індексу HOMA-IR в групі 2, а також покращення харчової поведінки, за даними опитувальників. Той факт, що в обох групах виявлено зниження екстернальної харчової поведінки при підвищенні обмежувальної, а у групі 2 ще і зниження емоційної, говорить про те, що у обстежених паціентів покращився контроль над своїми бажаннями стосовно неконтрольованого прийому їжі. Отже, за рахунок зниження інсулінорезистентності відбулося суттеве покращення харчової поведінки. Безумовно, для нормалізації харчової поведінки 21 дня вживання клітковини недостатньо, до того, як видно 3 нашого дослідження, саме доза 15 г клітковини з гуарової камеді на день е більш ефективною. Слід додати, що Американська асоціація дієтологів рекомендуе вживання 14 г клітковини на 1000 ккал [19]. Під час проведення дослідження в жодного з пацієнтів не було зафіксовано виражених побічних явищ. У 4 пацієнтів 3 другої групи незначний метеоризм, що спостерігався в 1-2 день застосування, минув без додаткових заходів.

Таким чином, додавання клітковини може покращити харчову поведінку та знизити інсулінорезистентність, ризики розвитку КВЗ, загальної смертності, знизить ризик респіраторних захворювань та покращить якість життя пацієнтів 3 надмірною вагою.

\section{ВИСНОВКИ}

У $95 \%$ пацієнтів з надмірною вагою та ожирінням виявлено порушення харчової поведінки, з перевагою обмежувального та екстернального типів. 
Додавання до раціону харчової клітковини у вигляді камеді гуарової мікрогранульованої Інгуар ${ }^{\mathrm{TM}}$ в дозі 15 г на добу протягом 21 дня знижуе інсулінорезистентність та нормалізуе харчову поведінку паціентів, а саме обмежувальну, емоціогенну та екс- тернальну, та може бути рекомендовано у комплексі заходів для зниження ваги у паціентів з підвищеним індексом маси тіла, інсулінорезістентістю та для нормалізації харчової поведінки.

\section{ЛITEPATУРА \\ (REFERENCES)}

1. Bergman RN, Kim SP, Hsu IR, et al. Am J Med 2007; 120(Suppl 1): S3-S8.

2. Dietz W, Santos-Burgoa C. Obesity (Silver Spring) 2020; 28(6): 1005.

3. American Diabetes Association. Diabetes Care 2018; 41(Suppl 1): S38-S50. https://doi.org/10.2337/dc18-S004.

4. Umeh AE, Nkombua L. Family Practice 2018; 60(1): 26 30. https://doi.org/10.1080/20786190.2017.1364012.

5. Dailey MJ, Moran TH. Trends Endocrinol Metab 2013; 24(2): 85-91.

6. Sternson SM, Eiselt AK. Annu Rev Physiol 2017; 79: 401-423.

7. Krude H, Biebermann H. Trends Mol Med 2019;25(2): 136-148.

8. Ju SH, Cho GB, Sohn JW. Pharm Res 2018;129; 10-19.

9. Campbell JN, Macosko EZ, Fenselau H, et al. Nat Neurosci 2017;20(3): 484-496.

10. Thaler JP, Guyenet SJ, Dorfman MD. Diabetes 2013; 62(8): 2629-2634.

11. Schwartz MW, Seeley RJ, Zeltser LM, et al. Endocr Rev 2017;38(4): 267-296

12. Hargrave SL, Jones S, Davidson TL. Curr Opin Behav Sci 2016;9: 40-46.

13. Lin Y, Wang K, Ma C, et al. Front Aging Neurosci 2018; 10: 227. https://doi.org/10.3389/fnagi.2018.00227.

14. Ackermann RT, Edelstein SL, Narayan KMV. Obesity (Silver Spring) 2009;17(12): 2176-2181.

15. Apovian CM. Curr Obes Rep 2014;3(2): 147-149.

16. Yumuk V, Tsigos C, Fried M, et al. Obes Facts 2015;8(6): 402-424.

17. Raynor HA, Champagne CM. J Acad Nutr Diet 2016; 116(1): 129-147.
18. Aaseth J, Ellefsen S, Alehagen U, et al. Biomed Pharmacother 2021;140: 111789. https://doi.org/10.1016/j.biopha.2021.111789.

19. Park Y, Subar AF, Hollenbeck A, Schatzkin A. Arch Intern Med 2011; 171(12): 1061-1068. https://doi.org/10. 1001/archinternmed.2011.18.

20. Pereira MA, O'Reilly E, Augustsson K, et al. Arch Intern Med 2004;164(4): 370-376. https://doi.org/10.1001/ archinte.164.4.370.

21. Ma Y, Griffith JA, Chasan-Taber L, et al. Am J Clin Nutr 2006;83: 760-766.

22. King DE, Egan BM, Geesey ME. Am J Cardiol 2003;92: $1335-1339$

23. Wannamethee SG, Whincup PH, THOMA-IR-IRs MC, Sattar N. Diabetes Care 2009;32: 1823-1825.

24. Ma Y, Hebert JR, Li W, et al. Nutrition 2008;24: 941949.

25. Pope Z, Gao Y, Bolter N, Pritchard M. J Sport Health Sci 2015; 4(3): 211-221. https://doi.org/10.1016/j.jshs. 2014.05.001.

26. Mojzrist OM. Aktual'ni problemy psyhologii': Zbirnyk naukovyh prac' Instytutu psyhologii' imeni G. S. Kostjuka, Kyi'v, 2012;10 (23): 431-440.

27. Brown L, Rosner B, Willett WW, Sacks FM. Am J Clin Nutr 1999;69: 30-42.

28. Pereira MA, Jacobs DR Jr, Pins JJ, et al. Am J Clin Nutr 2002;75: 848-855.

29. Zherdova NN, Mankovsky BN. Probl Endocrine Pathol 2021; 69(3): 7-13. https://doi.org/10.21856/j-PEP.2019. 3.01.

30. Filippi BM, Mighiu PI, Lam TKT. Diabetes 2012;61(4): 773-775. https://doi.org/10.2337/db12-0048. 


\title{
ВПЛИВ ВЖИВАННЯ ХАРЧОВОЇ КЛІТКОВИНИ НА ХАРЧОВУ ПОВЕДІНКУ У ПАЦІЄНТІВ 3 НАДМІРНОЮ ВАГОЮ ТА ОЖИРІННЯМ \\ Жердьова Н.M. ${ }^{1,2}$, Степура O.A. ${ }^{1}$, Костіцька I.O. ${ }^{3}$, Мазій C.I. ${ }^{1}$ \\ ${ }^{1}$ ДНУ "Центр інноващійних медичних технологій НАН Украӥни», м. Київ, Украӥна \\ ${ }^{2}$ Національний університет охорони здоров’я імені П.Л. Шупика МОЗ Украӥни, м. Київ, Україна \\ ${ }^{3}$ Івано-Франківський національний медичний університет, л. Івано-Франківськ, Украӥна nadejda05.1977@gmail.com
}

В статті наведені дані щодо впливу вживання харчової клітковини на стан харчової поведінки та метаболічних показників у паціентів з надмірною вагою та ожирінням (індекс маси тіла (IMT) більше $\left.25 \kappa \Gamma / \mathrm{M}^{2}\right)$.

Метою нашого дослідження було вивчити вплив прийому мікрогранульованої та очищеної гуарової камеді у формі препарату Інгуар ${ }^{\mathrm{TM}}$ на метаболічні показники та зміну харчової поведінки у паціентів з надмірною вагою та ожирінням.

Матеріали та методи. У дослідження тривалістю 21 день були включені паціенти обох статей старше 18 років, розподілені на 2 групи по 30 осіб. До першої групи входили пацієнти, які отримували препарат по 1 пак. (5 г) на вечір, до другої - які приймали препарат по 1 пак. 3 рази на день (15 г). В першій групі середній вік становив 53,95 $\pm 2,43$ роки, IMT $-33,35 \pm 1,02 \mathrm{\kappa} / \mathrm{m}^{2}$, у другій - середній

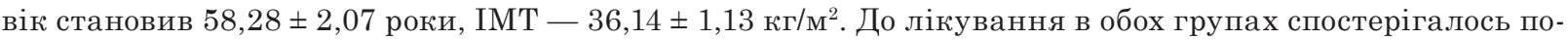
рушення харчової поведінки переважно за обмежувальним та екстернальним типом.

Результати. Додавання до раціону харчової клітковини у вигляді камеді гуарової мікрогранульованої Інгуар ${ }^{\mathrm{TM}}$ в дозі 15 г на добу протягом 21 дня знижувало інсулінорезистентність та нормалізувало харчову поведінку пацієнтів, а саме обмежувальну, емоціогенну та екстернальну. Вживання харчової клітковини може бути рекомендовано у комплексі заходів для зниження ваги у пацієнтів 3 підвищеним індексом маси тіла та інсулінорезістентістю, а також для нормалізації харчової поведінки.

К лючові слова : ожиріння, харчова поведінка, харчова клітковина, інгуар, камедь гуарова.

\section{EFFECT OF DIETARY FIBER INTAKE ON EATING BEHAVIOR IN OVERWEIGHT AND OBESE PATIENTS}

\author{
N. M. Zherdova ${ }^{1,2}$, O. A. Stepura ${ }^{1}$, I. O. Kostitska ${ }^{3}$, S. I. Mazii ${ }^{1}$ \\ ${ }^{1}$ Center for Innovative Medical Technologies the NAS of Ukraine, Kyiv, Ukraine; \\ ${ }^{2}$ Shupyk National Healthcare University, Kyiv, Ukraine; \\ ${ }^{3}$ Ivano-Frankivsk National Medical University, Ivano-Frankivsk, Ukraine \\ nadejda05.1977@gmail.com
}

The article presents data on the influence of dietary fiber intake on eating behavior and metabolic parameters in overweight and obese patients.

The aim of our study was to examine the effect of microgranular and purified Guar gum in the form of the dietary supplement Inguar on metabolic parameters and changes in eating behavior in overweight and obese patients.

Materials and methods. The 21-day study included patients of both sexes older than 18 years, divided into 2 groups of 30 people. The first group included patients who received the drug at 1 sachet (5 g) in the evening, the second - who received the drug at 1 sachet 3 times a day (15 g). In the first group, the average age was $53.95 \pm 2.43$ years, BMI $-33.35 \pm 1.02 \mathrm{~kg} / \mathrm{m}^{2}$. In the second ones the average age was $58.28 \pm 2.07$ years, $\mathrm{BMI}-36,14 \pm 1.13 \mathrm{~kg} / \mathrm{m}^{2}$. Prior to treatment, eating disorders were observed in both groups, mainly of the restricted and external type.

Results. After the treatment, we found a probable decrease in the HOMA-IR index in the group receiving $15 \mathrm{~g}$ of fiber. In both groups, the addition to the diet of dietary fiber in the form of guar gum in a dose of both $5 \mathrm{~g}$ and $15 \mathrm{~g}$ per day for 21 days normalizes the eating behavior, namely restrictive, emotional and external type. The use of dietary fiber can be recommended as a set of measures to lose weight in patients with high body mass index and insulin resistance, as well as to normalize eating behavior.

Key words: obesity, eating behavior, dietary fiber, inguar, guar gum. 